\title{
Nature of Insoluble Material Found in the Bottom of Soybean Biodiesel Storage Tank: Chemical and Microbiological Approach
}

\author{
Juciana C. Cazarolli, ${ }^{a}$ Gabriela Boelter, ${ }^{a}$ Amanda M. D. L. de Lima, ${ }^{a}$ Thaisa Hengles, ${ }^{b}$ Camila Correa ${ }^{b}$ \\ Maria C. R. Peralba, ${ }^{b}$ Marco F. Ferrão, ${ }^{*, b}$ Eduardo H. S. Cavalcanti, ${ }^{c}$ Márcia V. Bisol, ${ }^{d}$ \\ Kelly S. Bezerra, ${ }^{e}$ Nelson R. Antoniosi Filho ${ }^{e}$ and Fátima M. Bento ${ }^{a}$ \\ ${ }^{a}$ Laboratório de Biodeterioração de Combustíveis e Biocombustíveis (LAB-BIO), \\ Departamento de Microbiologia, Imunologia e Parasitologia, Universidade Federal do Rio Grande do Sul, \\ Rua Sarmento Leite, 500, 90050-170 Porto Alegre-RS, Brazil \\ ${ }^{b}$ Departamento de Química Inorgânica, Universidade Federal do Rio Grande do Sul, \\ Av. Bento Gonçalves, 9500, 91501-970 Porto Alegre-RS, Brazil \\ ${ }^{c}$ Divisão de Corrosão e Degradação, Instituto Nacional de Tecnologia, Av. Venezuela, 82, Sala 608, \\ 20081-312 Rio de Janeiro-RJ, Brazil \\ d3 Tentos/RS, Rodovia BR 285, km 461.5, Distrito Industrial, 98700-000 Ijuí-RS, Brazil \\ ${ }^{e}$ Laboratório de Métodos de Extração e Separação (LAMES), Instituto de Química, \\ Universidade Federal de Goiás, Campus Samambaia, CP 131, 74001-970 Goiânia-GO, Brazil
}

\begin{abstract}
During biodiesel storage, chemical reactions may occur, producing sludges. The aim of this study was to characterize the chemical and microbial composition of the sludge found in a biodiesel storage tank. The material was collected in a biodiesel production plant. The sludge chemical characterization was performed by Fourier transform infrared (FTIR) spectroscopy, flame atomic absorption spectroscopy (FAAS), gas chromatography (GC), and the microbial investigation used culture-dependent techniques. The deteriogenic potential of the native microbial community was evaluated using the sludge as a microbial inoculum in a 60 day experiment. The microbial growth, biodiesel degradation, $\mathrm{pH}$ alterations, and the detection of esters in the aqueous phase were evaluated. The chemical analysis indicated the sludge composition as fatty acids esters and metallic ions; sterols glycosides were not detected. Seven bacteria and five fungi species were obtained from the sludge. The microbial growth analysis indicated that the native community does not have high biodiesel deteriogenic capacity.
\end{abstract}

Keywords: biodeterioration, infrared spectroscopy, microorganisms, sludge, soybean biodiesel

\section{Introduction}

The use of biofuels derived from renewable raw materials has been increasingly common in the global energy field. In Brazil, with the approval of law $11.097 / 2005,{ }^{1}$ on January 13, 2005, biodiesel has been added to petroleum diesel. Currently, the concentration of biodiesel in mineral diesel is $10 \%$ (B10), and the perspective is that this percentage will increase in the following years in the country. The national production of biodiesel occurs mainly by transesterification reaction using methanol. ${ }^{2}$ The Brazilian National Agency of Petroleum, Natural Gas, and Biofuels (Agência Nacional do

*e-mail: mfferrao@gmail.com
Petróleo, Gás Natural e Biocombustíveis, ANP) Resolution No. $45 / 2014^{3}$ (henceforward called ANP 45) describes the quality requirements for commercialized biodiesel.

Because it is commonly composed of fatty acid methyl esters (FAMEs), biodiesel has a higher degradability than diesel. In case of an environmental accident, the higher degradability of biodiesel, when mixed with diesel, is advantageous. However, this feature can be a disadvantage in storage since it makes diesel/biodiesel blends more susceptible to microbial contamination. ${ }^{4}$ Biodiesel can also be composed of small amounts of other elements such as glycerol and some metallic ions. The ANP 45 determines the acceptable limit of concentrations of these substances in biodiesel. ${ }^{3}$ In addition, sterols glycosides from the 
original raw material can also be found in biodiesel after its production. ${ }^{5}$ During the biodiesel storage, chemical and biological reactions (oxidation, hydrolysis, and polymerization) can occur, resulting in the formation of insoluble solids. The solids may precipitate, creating sludge of viscous appearance at the bottom of the tanks, which can cause damage to the filtering and storage systems. ${ }^{6,7}$

A remarkable difference between biodiesel and diesel is the presence of oxygen atoms in the former, which makes it more polar and capable of creating hydrogen bonds with water. This hygroscopic feature increases the capacity of biodiesel to absorb large amounts of water and has affixed limit up to $200 \mathrm{mg} \mathrm{kg}^{-1} .3,7$ The addition of biodiesel to diesel may increase the precipitates formation due to the decrease of the medium polarity. ${ }^{7}$ The presence of sludge in storage tanks is an expected outcome from the storage of pure biodiesel and diesel to the use of current diesel/ biodiesel mixtures when tanks are not properly preserved. Over time, the appearance of a free-water phase in the storage tanks makes the environment suitable for microbial growth. The free-water phase also facilitates the reactions during the abiotic fuel degradation, such as oxidations and hydrolysis. The presence of a biomass at the fuel-water interface is confirmed by the visual verification of the microbial contamination in the tanks. ${ }^{4,8,9}$

The deteriogenic microorganisms in the bottom sediment of biodiesel storage tanks of production plants will be in contact with the biodiesel produced and will be carried along with it during transportation. Depending on the preservation techniques used in the preservation of storage tanks, when biodiesel is mixed with diesel microbial development may occur. The main consequences will be the premature saturation of filters and wear of the injection systems due to the biological material produced. According to the Brazilian legislation ABNT NBR 15512 (14), ${ }^{10}$ some simple measures adopted during the prevention of microbial growth in tanks, known as "Good Practices", such as the daily drainage of tanks, may prevent the accumulation of free water. ${ }^{4,9,11}$ The aim of this work was to characterize the nature of the sediment found in the bottom of commercial biodiesel storage tanks (with additives), and evaluate the deteriogenic potential of the native population (modified non-characterized inoculum ASTM E1259-16 $6^{12}$ standard) in a microbial growth experiment of up to 60 days.

\section{Experimental}

Sampling the bottom content of the storage tank

The sampling was carried out in a soybean biodiesel plant in the municipality of Ijuí, northern Rio Grande do Sul State.
After permission provided by the plant board of directors, a $2000 \mathrm{~m}^{3}$ capacity storage tank was opened and the ballast content was drained. The remaining material left in the ballast was aseptically collected; it had a viscous appearance, as seen in Figure 1. The sludge was stored at room temperature and evaluated according to its chemical and microbiological characteristics based on analyses described below.

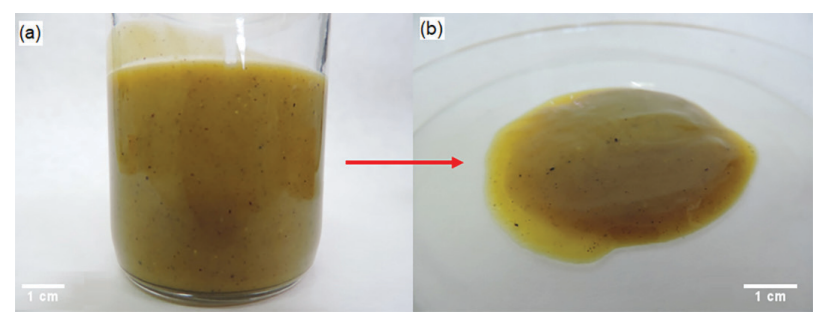

Figure 1. Aspect of the material collected from a commercial biodiesel storage tank of the biodiesel plant. (a) Collection flasks containing the sludge; and (b) a portion of the sludge sample in a Petri dish for appearance observation.

\section{Chemical characterization}

\section{Infrared spectroscopy}

To achieve the solid phase decomposition, $500 \mathrm{mg}$ of the sludge as sampled was transferred to microwave oven quartz flasks with a maximum volume capacity of $80 \mathrm{~mL}$. Afterwards, $3 \mathrm{~mL}$ of $\mathrm{HNO}_{3}$ (Vetec, PA), $1 \mathrm{~mL}$ of $\mathrm{H}_{2} \mathrm{O}$ (Milli-Q), and $2 \mathrm{~mL}$ of $\mathrm{H}_{2} \mathrm{O}_{2}$ (Merck) were added. The vials were closed and put into an Anton Paar Multiwave PRO microwave oven, using the following heating program: $20 \mathrm{~min}$ on heating ramp (up to $900 \mathrm{~W}$ ), hold for $20 \mathrm{~min}($ at $900 \mathrm{~W})$, and $20 \mathrm{~min}$ cooling $(0 \mathrm{~W})$. The maximum temperature and pressure were $220{ }^{\circ} \mathrm{C}$ and 80 bar, respectively.

The sludge sample was then solubilized in chloroform and filtered. The solid part was dried prior to the Fourier transform infrared (FTIR) spectroscopy/attenuated total reflectance (ATR) procedure on an Agilent Cary spectrophotometer coupled with an ATR accessory with $\mathrm{ZnSe}$ crystal. The spectrum was obtained in triplicate in the $4000-750 \mathrm{~cm}^{-1}$ range at room temperature with a resolution of $4 \mathrm{~cm}^{-1}$ and 32 scans.

Analysis of the presence of steroids by high performance liquid chromatography (HPLC)-tandem mass spectrometry (MS/MS)

The analyses of the different steroid classes were performed using a triple quadrupole MS/MS (SCIEX) mass sequencing coupled to an HPLC system. The atmospheric pressure chemical ionization (APCI) was used as the ionization source, using the multiple reaction monitoring (MRM) for quantification. Chromatographic separations 
were performed on a $\mathrm{C}-18$ Poroshell 120 column $(50 \mathrm{~mm} \times 4.6 \mathrm{~mm} \times 2.7 \mu \mathrm{m})$. The entire HPLC-MS/MS system was controlled by the software Analyst 1.5.2. Table 1 shows the particularities of each testing method for each steroid class. The sample was prepared by solubilizing $1 \mathrm{~mL}$ in $10 \mathrm{~mL}$ of dichloromethane (Vetec, PA).

The following steroids were monitored: $\beta$-sitosterol, avenasterol, brassicasterol, campesterol, cholesterol, desmosterol, estigmastanol, estigmasterol, lanosterol, and latosterol. To monitor the presence of free steroids, the fragments generated from the $[\mathrm{M}-\mathrm{OH}]^{+}$ion were considered. To monitor the presence of esterified steroids, the bonding of each free steroid to a different fatty acid was considered for the formation of steroid esters. The following fatty acids were confirmed: myristic (C14:0), palmitic acid (C16:0), palmitoleic (C16:1), stearic acid (C18:0), oleic acid (C18:1), linoleic acid (C18:2), linolenic acid (C18:3), arachidic (C20:0), and behenic (C22:0). The fragments generated from the ion $\left[\mathrm{M}+\mathrm{NH}_{4}\right]^{+}$were considered for monitoring free steroids. To monitor the presence of glucosides steroids, the bonding between each free steroid to one glucose molecule $\left(\mathrm{C}_{6} \mathrm{H}_{12} \mathrm{O}_{6}\right)$ was considered. Thus, fragments generated from the ion $\left[\mathrm{M}+\mathrm{H}_{2} \mathrm{O}\right]^{+}$were considered for the analyses. Finally, the detection of glucosides steroids was based on the formation of glucoside steroid esters with each previously mentioned fatty acid. The fragmentation reactions were confirmed by the presence of the ion $\left[\mathrm{M}+\mathrm{H}_{2} \mathrm{O}\right]^{+}$.

\section{Inorganic analysis}

The concentrations of sodium $(\mathrm{Na})$, potassium $(\mathrm{K})$, calcium $(\mathrm{Ca})$, and magnesium $(\mathrm{Mg})$ were evaluated by flame atomic absorption spectroscopy (FAAS) in an Analyst 200 spectrometer (PerkinElmer). The used standards (Na, $\mathrm{K}, \mathrm{Ca}$, and $\mathrm{Mg}$ ) followed the Fluka brand specifications, in a concentration of $1000 \mathrm{mg} \mathrm{L}^{-1}$. A Shinkell solution $\left(10 \mathrm{~g} \mathrm{~L}^{-1} \mathrm{Cs}+100 \mathrm{~g} \mathrm{~L}^{-1} \mathrm{La}\right)$ was used to detect $\mathrm{Na}$ and $\mathrm{K}$ ions. The analysis conditions of each element are displayed in Table 2.

Microbial investigation

Prospecting culturable microorganisms

A $2.5 \mathrm{~g}$ sludge aliquot was added to Erlenmeyer flasks containing $40 \mathrm{~mL}$ of sterile soybean biodiesel (as oil phase)

Table 1. Experimental conditions of steroid analysis methods

\begin{tabular}{|c|c|c|c|c|c|}
\hline Steroid class & $\begin{array}{l}\text { Spectral scanning } \\
\text { range } / \mathrm{m} / \mathrm{z}\end{array}$ & $\begin{array}{l}\text { Temperature of the } \\
\text { APCI-MS/MS } \\
\text { ionization source } /{ }^{\circ} \mathrm{C} \\
\end{array}$ & $\begin{array}{c}\text { Mobile phase composition in the } \\
\text { HPLC }\end{array}$ & $\begin{array}{l}\text { Mobile phase } \\
\text { flow / }\left(\mu \mathrm{L} \mathrm{min}{ }^{-1}\right)\end{array}$ & $\begin{array}{l}\text { Sample injection } \\
\text { volume / } \mu \mathrm{L}\end{array}$ \\
\hline Free steroids $(\mathrm{S})$ & $300-450$ & 400 & $\begin{array}{c}\text { acetonitrile + dichloromethane } \\
\text { gradient: } \\
90+10 \%(\mathrm{v} / \mathrm{v}) 0-6 \mathrm{~min} \\
85+15 \%(\mathrm{v} / \mathrm{v}) 6-7 \mathrm{~min} \\
75+25 \%(\mathrm{v} / \mathrm{v}) 7-11 \mathrm{~min}\end{array}$ & 1000 & 5 \\
\hline Esterified steroids (ES) & $600-800$ & 430 & $\begin{array}{l}\text { methanol + chloroform (6:4) with the } \\
\text { addition of } 200 \mathrm{mM} \text { of ammonium } \\
\text { acetate for } 10 \mathrm{~min}\end{array}$ & 1000 & 10 \\
\hline Glucosides steroids (SG) & $500-650$ & 350 & $\begin{array}{l}\text { methanol + water gradient } \\
\text { (with } 1 \% \text { acetonitrile): } \\
85+15 \%(\mathrm{v} / \mathrm{v}) 0-15 \mathrm{~min} \\
100 \% \text { of methanol } 15-18 \mathrm{~min} \\
75+25 \%(\mathrm{v} / \mathrm{v}) 18-20 \mathrm{~min}\end{array}$ & 800 & 10 \\
\hline $\begin{array}{l}\text { Acylated glucoside } \\
\text { steroids (ASG) }\end{array}$ & $750-950$ & 350 & $\begin{array}{l}\text { methanol }+ \text { water gradient } \\
\text { (with } 1 \% \text { acetonitrile): } \\
85+15 \%(\mathrm{v} / \mathrm{v}) 0-5 \mathrm{~min} \\
100 \% \text { methanol } 5-30 \mathrm{~min}\end{array}$ & 1200 & 10 \\
\hline
\end{tabular}

APCI-MS/MS: atmospheric pressure chemical ionization-tandem mass spectrometry; HPLC: high performance liquid chromatography.

Table 2. Conditions for the FAAS analysis for each analyte

\begin{tabular}{|c|c|c|c|c|}
\hline Analyte & $\begin{array}{c}\text { Compressed air oxidant } \\
\text { flow / }\left(\mathrm{L} \mathrm{min}^{-1}\right)\end{array}$ & $\begin{array}{l}\mathrm{C}_{2} \mathrm{H}_{2} \text { fuel flow / } \\
\left(\mathrm{L} \mathrm{min}^{-1}\right)\end{array}$ & Slit / mm & Wavelength / nm \\
\hline K & 10 & 2.5 & $2.7,0.45$ & 766.49 \\
\hline $\mathrm{Na}$ & 10 & 2.5 & 1.8 & 589 \\
\hline $\mathrm{Mg}$ & 8.5 & 4.0 & $2.7,1.05$ & 285.21 \\
\hline $\mathrm{Ca}$ & 10 & 2.7 & $2.7,0.6$ & 422.67 \\
\hline
\end{tabular}


and $80 \mathrm{~mL}$ of Bushnell Haas minimal mineral medium ${ }^{13}$ (henceforth called BH medium) or $80 \mathrm{~mL}$ of ultrapure water (aqueous phase solution with different nutrient inputs). The Erlenmeyer flasks were stored for 20 days in a static culture and in an orbital shaker at $30{ }^{\circ} \mathrm{C}$, in triplicate. The experiment was evaluated after 0,2, 24 and $48 \mathrm{~h}$, and 5, 7, 15 and 20 days. At each evaluation, serial decimal dilution and subsequent seeding in different culture media were performed. The used culture media were plate count agar (PCA, culture medium for bacterial counting), malt agar (culture medium for fungi), tryptic soy agar (TSA, culture medium for bacteria), and Reasoner's 2A agar (R2A, culture medium for slow-growing bacteria). These procedures were performed to stimulate microbial growth and enable the isolation of as many cultivable microorganisms as possible.

\section{Culturable isolates identification}

After the microbial prospection, the molecular identification of the isolates was carried out through DNA sequencing. The fungal DNA extraction was performed according to Ferreira and Grattapaglia; ${ }^{14}$ the bacterial DNA extraction was performed with the PureLink ${ }^{\circledR}$ Genomic DNA Kit. Afterwards, the amplification of the internal transcribed spacer (ITS) region through polymerase chain reaction (PCR) was executed. The amplification separated the fungal $18 \mathrm{~S}$ and $28 \mathrm{~S}$ rDNA genes and the bacterial $16 \mathrm{~S}$ gene. The bacterial identification was initiated by Gram staining, cell and colonial morphology, and subsequently by PCR amplification of the 16S gene. This amplification was performed using the primers AGAGTTTGATCCTGGCTCAG (F-C27) and CCGCGGCTGCTGGCACGTA (R-530), generating a $530 \mathrm{pb}$ product. The identification of the filamentous fungi was initially performed by the microculture technique and later through PCR. The amplification of the ITS-5.8S-ITS2 region was achieved using the primers TCCGTAGGTGAACCTCGCG (ITS-1) and TCCTCCGCTTATTGATATGC (ITS-4), generating a $550 \mathrm{pb}$ product. PCR products were purified using the Invitrogen PureLink ${ }^{\mathrm{TM}}$ PCR purification kit. Sequencing reactions were performed using the BigDye ${ }^{\circledR}$ Terminator V3.1 cycle sequencing reaction kit (Applied BioSystems) following the manufacturer's instructions. Then, the fragments analyses were run through the ABI Prism 3130 genetic analyzer automatic sequencer (Applied BioSystems). The generated sequences were compared with the GenBank database ${ }^{15}$ online tool for for identification, and submitted afterwards to the Genbank database.

After isolation and identification, the microorganisms were characterized according to the lipase enzyme production through the inoculation of the media tributyrin agar and rhodamine B. ${ }^{16}$ The lipase is involved in the biodiesel biodegradation.

\section{Biodiesel sludge deteriogenic capacity}

The microcosms were settled in glass flasks containing $60 \mathrm{~mL}$ of sterile Bushnell Haas ${ }^{13}$ medium and $30 \mathrm{~mL}$ of oil phase biodiesel (pure commercial soybean biodiesel, B100). Three treatments were evaluated according to the level of microbial contamination. The control treatment (CTE, sterile commercial biodiesel) was comprised of an oily phase sterilized through vacuum filtration system in a Kitasato flask with $0.22 \mu \mathrm{m}$ porosity membranes (Millipore). The as-received treatment ( $\mathrm{CR}$, as-received commercial biodiesel) was comprised of the oily phase as received from the distributor, contaminated by its manipulation during the biodiesel distribution chain. The sterile commercial biodiesel with inoculum (BI) was the only treatment that received inoculum; $500 \mathrm{mg}$ of the sludge from the storage tank ballast was added into the BI treatment (ASTM E1259-16 ${ }^{12}$ standard). The experiment was carried out in triplicate and the flasks were incubated in an oven at $30{ }^{\circ} \mathrm{C}$ for 60 days. The flasks were periodically shaken (every 5 days at $90 \mathrm{rpm}$ and $30{ }^{\circ} \mathrm{C}$ for $30 \mathrm{~min}$ ) in order to simulate the supply and withdrawal of fuel from the tanks in the biodiesel plant.

During the shaking, some sludge components from the BI treatment showed a higher dilution into the biodiesel and/or in the aqueous phase when compared with the initial treatments stages. Due to this dilution, the initial added weight was disregarded $(500 \mathrm{mg})$. To quantify the initial sludge weight in order to estimate the microbial growth, a post-dilution determination of the inoculum was performed at the initial time of the entire flasks composition in triplicate. All previous determined conditions of the experiment were respected.

At the sampling times $0,2,10,20,30,40,50$, and 60 days, the microbial growth was evaluated by the quantification of the total biomass formed at the oil-water interface of each flask by gravimetric method (dry weight). At 60 days, the aqueous phase of the CR treatment was inoculated into Petri dishes with culture medium for the isolation of fungi and bacteria (malt agar and PCA). The inoculation aimed to identify the biomass produced by the resident biodiesel microbiota. The most prevalent morphotype was identified through the analyzes described previosly here.

At the initial and final experimental times, the $\mathrm{pH}$ of the aqueous phase was evaluated. At days 2 and 60, the aqueous phases of all the treatments were evaluated by gas chromatography-flame ionization detector (GC-FID). 
The GC-FID enables the observation of the biodiesel compounds that could have migrated to the aqueous phase and their respective consumption by the microorganisms from the contaminated treatments. A quantity of $10 \mathrm{~mL}$ of aqueous phase was extracted by three sequential washes with $20 \mathrm{~mL}$ of dichloromethane (PA, Merck) and subsequently concentrated up to $500 \mu \mathrm{L}$. The sample was transferred to a $1.5 \mathrm{~mL}$ vial to which $130 \mu \mathrm{L}$ of methyl nonadecanoate (internal standard, Sigma) was added. Afterwards, the sample volume was completed up to $1 \mathrm{~mL}$ with dichloromethane and internal standard. The samples were injected into a Shimadzu GC-17A equipped with an Agilent EN 14103 column. The esters in the aqueous phase were identified by the following analysis conditions: injector and detector at $250{ }^{\circ} \mathrm{C}$, column at $100^{\circ} \mathrm{C}$ followed by heating at $4{ }^{\circ} \mathrm{C} \mathrm{min}^{-1}$ to $240{ }^{\circ} \mathrm{C}$ for $25 \mathrm{~min}$ in isotherm condition.

The initial and final times of the oil phase were evaluated by infrared spectroscopy to identify possible changes in the carbonic chains of biodiesel caused by microbial growth. The samples corresponding to the initial time (B100 t0: biodiesel without the addition of aqueous phase and/or inoculum) and the final time of all treatments (CTE t60: control; CR t60: as received; and BI t60: sludge as inoculum) were evaluated.

\section{Statistical analyses}

The data obtained were statistically analyzed using the XLSTAT-Pro $2014{ }^{17}$ software (Addinsoft's core software). Analysis of variance and Tukey test at the 5\% significance level were performed. The evaluation of the data generated by the infrared spectroscopy technique was performed with the Chemostat ${ }^{18}$ software.

\section{Results}

\section{Sludge chemical analysis}

The material collected from the bottom of the tanks had a viscous appearance. Figure 2 shows the spectrum of infrared analysis which presented a band approximately at the $1740 \mathrm{~cm}^{-1}$ region, related to the vibrations of the carbonyl group of esters $(\mathrm{C}=\mathrm{O})$. The absorption bands at regions 1080 to $1030 \mathrm{~cm}^{-1}$ were related to the vibrations of the aliphatic esters constituting the biodiesel. Bands at regions 2970 to $2840 \mathrm{~cm}^{-1}$ can be attributed to the vibrations of the $\mathrm{C}-\mathrm{H}$ bonds of the methyl $\left(\mathrm{CH}_{3}\right)$ and methylene $\left(\mathrm{CH}_{2}\right)$ groups. The absorption presented at region $3400 \mathrm{~cm}^{-1} \mathrm{can}$ be attributed to the vibrations of - $\mathrm{OH}$ groups.

According to these results of the solid phase chemical analysis, the sludge collected was predominantly composed by fatty acid esters. The FAAS analysis showed a high concentration of $\mathrm{Na}\left(10.8 \pm 0.54 \mathrm{mg} \mathrm{g}^{-1}\right)$ and a low concentration of $\mathrm{K}\left(26.1 \pm 0.29 \mu \mathrm{g} \mathrm{g}^{-1}\right)$, $\mathrm{Ca}\left(18.3 \pm 0.54 \mu \mathrm{g} \mathrm{g}^{-1}\right)$ and $\mathrm{Mg}\left(26.1 \pm 0.29 \mu \mathrm{g} \mathrm{g}^{-1}\right)$.

The main classes of steroids were evidenced when the insoluble material was evaluated. The chromatograms obtained during the steroid analysis by HPLC-MS/MS did not characterize the studied material as a steroid compound (Figure 3). Based on these results, it was not possible to detect or even quantify any steroids glucosides in the studied matrix. The signal strength was very low compared with the limits of the methods used.

Microbial investigation: isolation of cultivable microorganisms

Seven bacteria and five filamentous fungi species were prospected and identified. All filamentous fungi were

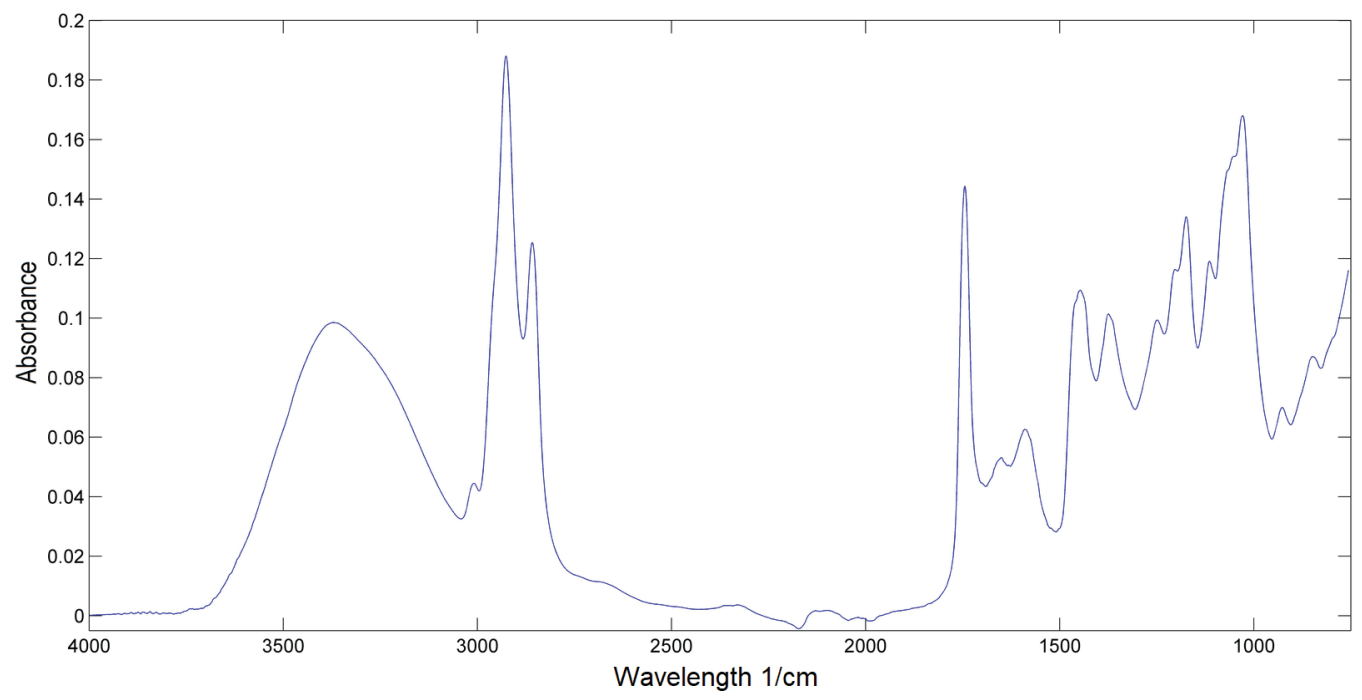

Figure 2. Average infrared spectrum of the biodiesel storage tank sludge sample. 

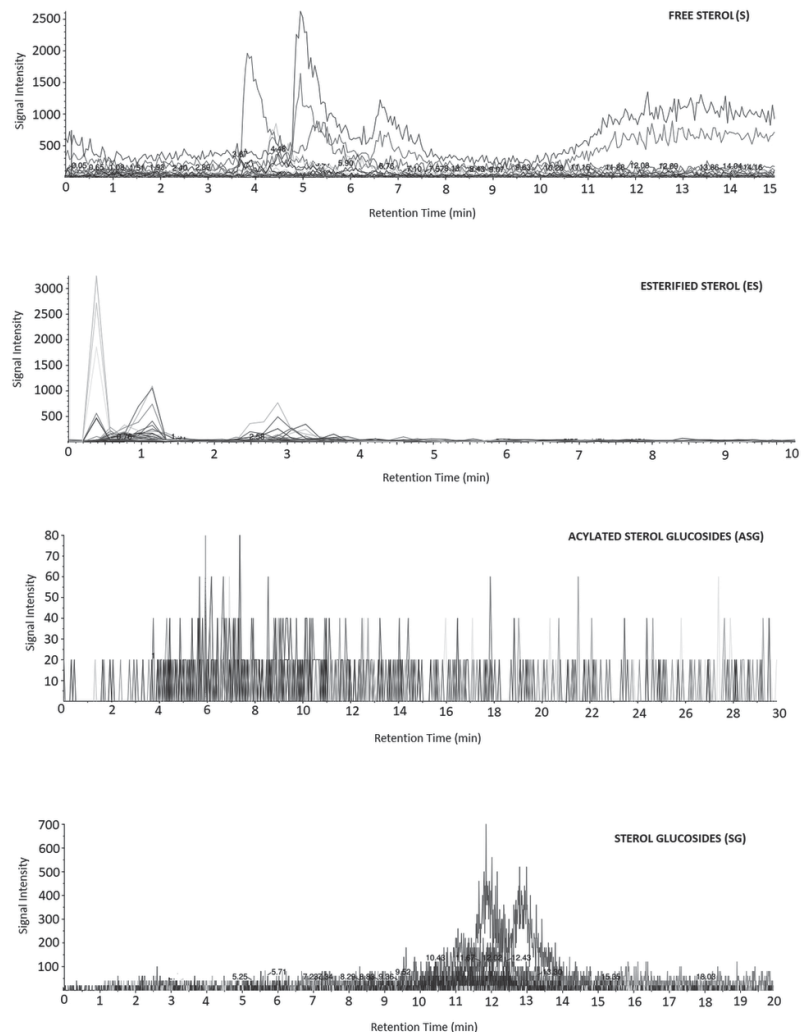

Figure 3. Chromatograms obtained from the analysis of the main steroid classes by HPLC-MS/MS.

isolated from the shaking and $\mathrm{BH}$ medium treatments. A total of five different bacteria were isolated from the shaking treatment whereas static cultivation only favored the appearance of two bacterial isolates. The use of ultrapure water did not favor the isolation of microorganisms since the same isolates were also recovered in the $\mathrm{BH}$ medium.
The identification results obtained for each isolate and the GenBank accession numbers are described in Table 3. After isolation, the microorganisms were inoculated in the rhodamine B and tributyrin media; the results are shown in Table 3. Nine microorganisms showed enzymatic activity in the tributyrin medium. Among these, only five had activity in rhodamine B as well.

\section{Deteriogenic capacity of sludge native microorganisms}

\section{Microbial growth}

The weight of the flasks of the BI treatment did not reach, in any of the evaluated times, the initial weight of $500 \mathrm{mg}$. This result suggests that there was a dilution of the sludge components in the microcosm phases. In comparison with flasks of the CR treatment, no visual growth was observed at the oil-water interface of all flasks of the BI treatment. The CR treatment had biomass statistically different from that obtained in the controls only after 40 days of analysis. This feature indicates that the native microbial population was probably in a low density. However, after 60 days, the biomass recovered from the interface of the flasks was $52.9 \pm 9.9 \mathrm{mg}$, six times the biomass recovered from the same treatment at 2 days of incubation $(8.9 \pm 3.7 \mathrm{mg})$.

Figure 4a shows the dark-colored biomass originated from the growth of native microorganisms in the commercial biodiesel. After 60 days, the prospection of the PCA medium indicated the presence of the black yeast Aureobasidium pullulans (Figures $4 \mathrm{~b}$ and $4 \mathrm{c}$ ), molecularly identified as described in the Experimental section. ${ }^{19}$ For the BI treatment the presence of retained biomass was

Table 3. Identification using Sanger sequencing and enzymes detection of the isolates obtained from the sludge

\begin{tabular}{|c|c|c|c|c|}
\hline LAB-BIO strain & Identification & Accession No. (GenBank) & Rhodamine B medium ${ }^{\mathrm{a}}$ & Tributyrin medium ${ }^{\mathrm{a}}$ \\
\hline LABBIO2 & Xylariales sp. & MG595218 & - & - \\
\hline LABBIO3 & Penicillium citrinum & MG595219 & + & + \\
\hline LABBIO4 & Penicillium simplicissimum & MG595220 & - & + \\
\hline LABBIO5 & Penicillium corylophilum & MG595221 & + & + \\
\hline LABBIO6 & Hypocreales sp. & MG595222 & + & + \\
\hline LABBIO7 & Micrococcus luteus & MG595223 & - & + \\
\hline LABBIO8 & Microbacterium sp. & MG595224 & - & - \\
\hline LABBIO9 & Cellulomonas sp. & MG595225 & - & - \\
\hline LABBIO10 & Curtobacterium sp. & MG595226 & - & + \\
\hline LABBIO11 & Bacillus megaterium & MG595227 & - & + \\
\hline LABBIO12 & Bacillus sp. & MG595228 & + & + \\
\hline LABBIO13 & Bacillus pumilus & MG595229 & + & + \\
\hline
\end{tabular}

aRhodamine and tributyrin medium were utilized on detection of enzymes related to degradation of esters. LAB-BIO: Laboratório de Biodeterioração de Combustíveis e Biocombustíveis. 
not detected in the filter, only particulate material of non-biological nature, resulting from abiotic degradation products (Figure $4 \mathrm{~d}$ ).
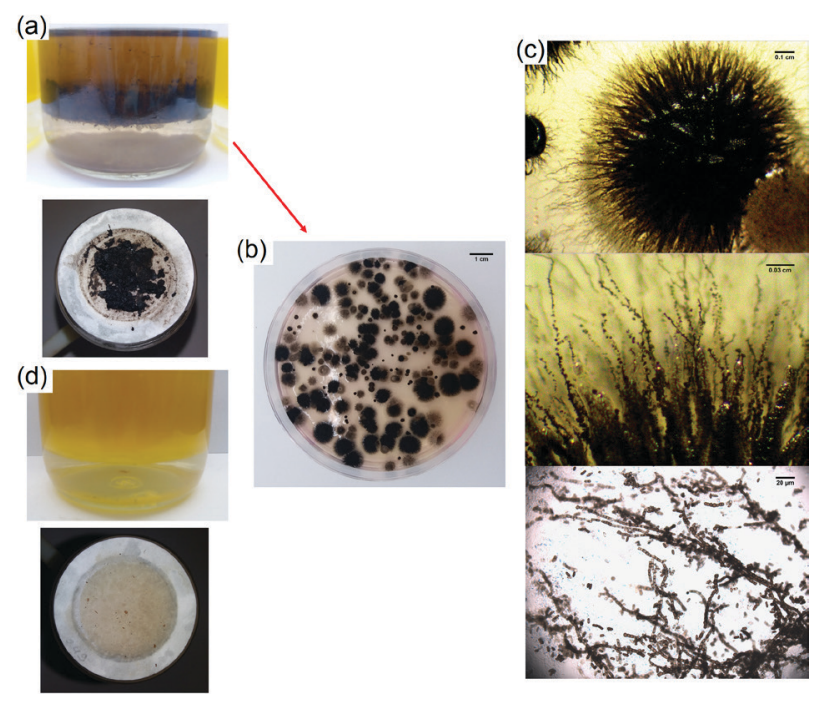

Figure 4. Aspect of the experimental flasks with the oil phase (biodiesel) and the aqueous phase at the end of 60 days of the experiment. (a) Treatment with commercial biodiesel as received (CR); (b) detail of CR treatment; appearance of the yeast colonies in the culture medium; (c) photomicrographs of the yeast Aureobasidium pullulans; and (d) treatment with sterile biodiesel inoculated with sludge (BI) and appearance of biomass retained on the filter membrane.

\section{$\mathrm{pH}$ measurements}

In comparison with the control flasks, the $\mathrm{pH}$ of the aqueous phase of the BH medium treatment suggests a tendency towards the acidification of this medium from 40 days of incubation of contaminated microcosms $(p<0.05)$. Comparing the two contaminated treatments, the $\mathrm{pH}$ remained similar until the end of the experiment, reaching $6.63 \pm 0.11(\mathrm{CR})$ and $6.65 \pm 0.10(\mathrm{BI})$ $(p>0.05)$.
Evaluation of the migration of biodiesel compounds to the aqueous phase and their consumption by the microbial community of the samples

Compounds identified as fatty acid esters were detected in the aqueous phase; their respective concentrations are displayed in Table 4. There was also the detection of peaks of some compounds in the samples in the GC-FID chromatograms; however, they were not correlated with any expected biodiesel ester. Long-chain esters (larger than 16 carbons) were detected in the aqueous phase of all treatments in days 2 and 60. Some esters with chains larger than 20 carbons were also detected in some samples (CTE t2, CR t2 and t60, and BI t60). No statistical differences were observed in the quantity of all esters detected under the control conditions and in the $\mathrm{CR}$ treatment. A significant reduction in the concentration of the C16, C18, C18:1, C18:2, and C18:3 esters after 60 days of incubation was observed in the BI treatment. Esters, such as C22:1 and/or C20:3, found in two samples (CR $\mathrm{t} 2$ and BI t60) could not be separated by the applied chromatography conditions.

\section{FTIR analysis: biodegradation of the oil phase}

The set of spectra generated from the oil phase of all treatments by the infrared technique is shown in Figure 5. The results indicate that there was no significant degradation throughout the conditions imposed by the experiments. The spectral data were evaluated by the principal component analysis (PCA); the score graph is presented in Figure 6. Using two main components, the results indicate that $91.68 \%$ of the data variance were explained. According to the weight chart of the first component, the main difference between the samples was the region of the carbonyl band. The results of PC1 suggest that sample B100 t0, i.e., how the biodiesel was before the experiment, separated from

Table 4. Concentration of the fatty acid esters detected by GC-FID in the aqueous phase after 2 and 60 days of experiment

\begin{tabular}{|c|c|c|c|c|c|c|}
\hline $\begin{array}{l}\text { Ester detected in } \\
\text { aqueous phase / } \\
\left(\mu \mathrm{g} \mathrm{mL} L^{-1}\right)\end{array}$ & CTE t2 & CTE t60 & $\mathrm{CR}$ t2 & CR t60 & BI t2 & BI t60 \\
\hline $\mathrm{C} 16$ & $56.9 \pm 2.9^{\mathrm{ab}}$ & $43.3 \pm 9.9^{b}$ & $40.3 \pm 9.9^{b}$ & $52.4 \pm 9.6^{\mathrm{b}}$ & $154.1 \pm 12.0^{\mathrm{a}}$ & $41.4 \pm 6.1^{\mathrm{b}}$ \\
\hline $\mathrm{C} 18$ & $24.1 \pm 1.3^{\mathrm{ab}}$ & $17.5 \pm 4.4^{\mathrm{b}}$ & $16.4 \pm 4.1^{\mathrm{b}}$ & $24.0 \pm 3.7^{\mathrm{b}}$ & $61.6 \pm 4.0^{\mathrm{a}}$ & $16.2 \pm 2.4^{\mathrm{b}}$ \\
\hline C18:1 & $123.0 \pm 2.8^{\mathrm{ab}}$ & $99.6 \pm 18.6^{\mathrm{b}}$ & $94.2 \pm 13.3^{\mathrm{b}}$ & $132.5 \pm 17.3^{b}$ & $314.1 \pm 38.9^{\mathrm{a}}$ & $97.7 \pm 14.1^{\mathrm{b}}$ \\
\hline C18:2 & $270.4 \pm 7.4^{\mathrm{ab}}$ & $219.0 \pm 42.5^{\mathrm{b}}$ & $206.4 \pm 24.6^{\mathrm{b}}$ & $249.3 \pm 92.0^{\mathrm{b}}$ & $708.9 \pm 89.4^{\mathrm{a}}$ & $213.7 \pm 27.6^{b}$ \\
\hline $\mathrm{C} 18: 3$ & $32.9 \pm 0.7^{\mathrm{ab}}$ & $26.5 \pm 5.5^{\mathrm{b}}$ & $24.5 \pm 2.5^{\mathrm{b}}$ & $25.5 \pm 13.0^{\mathrm{b}}$ & $84.5 \pm 9.9^{\mathrm{a}}$ & $25.3 \pm 2.7^{\mathrm{b}}$ \\
\hline C20:1 & - & - & $17.4 \pm 0.0$ & - & - & - \\
\hline C20:4 & $8.7 \pm 0.0$ & - & - & $13.4 \pm 0.0$ & - & - \\
\hline $\mathrm{C} 22: 1$ and/or $\mathrm{C} 20: 3$ & - & - & $18.9 \pm 0.0$ & - & - & $8.2 \pm 1.4$ \\
\hline
\end{tabular}

In each row, values among treatments with the same superscript letter were statistically indistinguishable by Tukey's test $(p>0.05)$. CTE: control treatment; t2: after 2 days of experiment; t60: after 60 days of experiment; BI: treatment with the sludge as an inoculum; CR: treatment as received. 
the other evaluated groups with positive scores. In the perspective of PC2 results, the samples were separated between CR t60 (with positive scores) and CTE t60, BI t0, and BI t60 (with negative scores).

\section{Discussion}

\section{Sludge characterization}

Many studies have shown the composition of the sediments found in biodiesel storage tanks. ${ }^{5,6,20}$ However, its microbial deteriogenic potential and composition has not yet been elucidated. The results from chemical analysis were concordant with the literature, where Bondioli ${ }^{21}$ found similar results when evaluating related material. This author attributed the absorption at regions 1730 and $3400 \mathrm{~cm}^{-1}$ to ester bonds and alcoholic groups, respectively. However, other authors have found elements in similar material which were not detected by our analyses. Plata et $a l .{ }^{20}$ identified insoluble materials from palm oil biodiesel as monopalmitin (saturated monoglyceride) and glycoside sterols. Bondioli ${ }^{21}$ identified saturated monoglycerides and fatty acids in sediments from soybean biodiesel. Sludge found in biodiesel from other raw materials, such as bovine tallow, was also identified as being predominantly composed of monopalmitin and monostearin monoglycerides. ${ }^{22}$

During the biodiesel production process, non-esterified fatty acids, or those still in esterification process, could be found in the oil phase. Mono-, di-, and triglycerides, along with other biodiesel impurities, can react and precipitate if

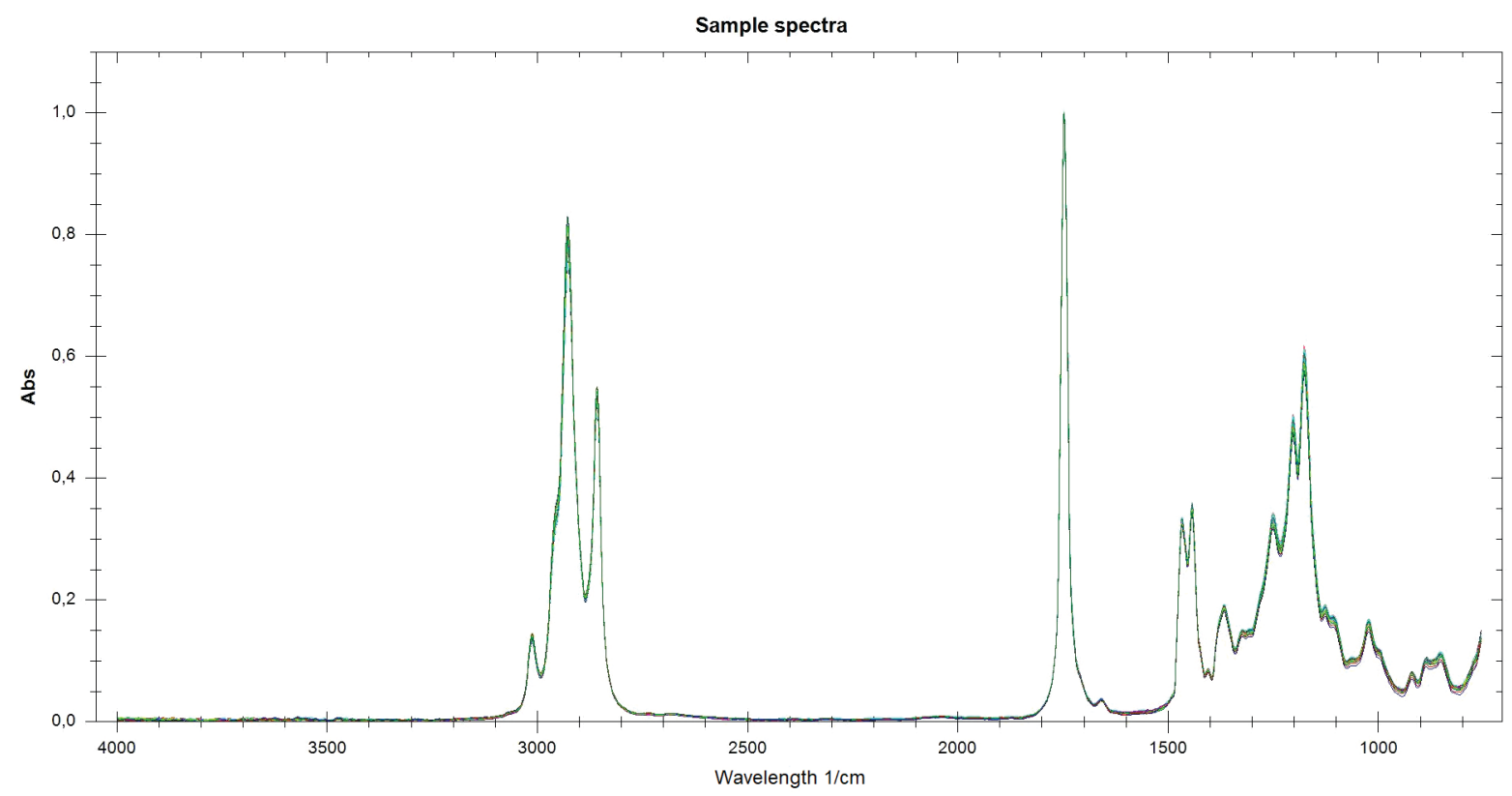

Figure 5. Infrared spectra of the biodiesel samples collected before and after 60 days of incubation at $30^{\circ} \mathrm{C}$.

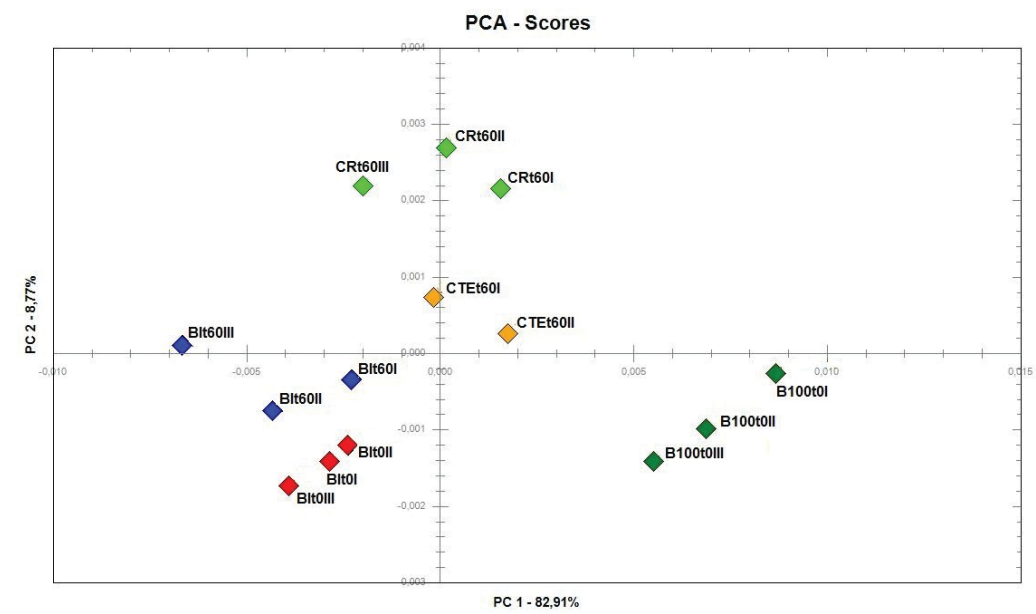

Figure 6. PCA analysis of data generated by infrared spectra of biodiesel samples collected before and after 60 days of incubation at $30{ }^{\circ} \mathrm{C}(\mathrm{B} 100$ : initial oil phase treatment; CTE: control treatment; CR: treatment as received; and BI: treatment as inoculum). 
not completely removed during the purification procedure of the transesterification reaction, forming the sludge found in the bottom of the plant storage. ${ }^{7,23}$ Also, the presence of compounds with low solubility in biodiesel, such as sterol glycosides, has been considered the main cause of the formation of sediments. ${ }^{5,6,20}$ Another important aspect of the sediment formation in biodiesel is its oxidative stability. During the storage period, this property can enhance the risk of sediment formation. A biodiesel with low oxidation stability can increase the concentration of free fatty acids in the fuel, increasing the viscosity and forming gums and deposits. $^{24}$

Pinho et al. ${ }^{25}$ identified bands at regions 1680 to $1820 \mathrm{~cm}^{-1}$ in biodiesel after an accelerated aging process. The authors attributed these bands to carboxylic acids, ketones, and aldehydes resulting from the oxidation of biodiesel constituents. The spectra generated by these oxidation products can raise the absorption at the region of $1740 \mathrm{~cm}^{-1}$, which could falsely increase the amount of esters detected. However, except for the ester band $(\mathrm{C}=\mathrm{O})$, no other bands were observed in this spectral band in our infrared spectrum.

Some authors suggest that steroids glucosides are the steroid class most prone to biodiesel precipitation, mainly due to their high polarity in comparison with fatty acid esters. ${ }^{6,26}$ However, other authors claim that these compounds may lead to the interconversion between their classes (free, esterified, glucosides, and acyl glucosides). ${ }^{27}$ Sterol glucosides were not found in the sample evaluated in our study; nevertheless, the inorganic analysis demonstrated the presence of inorganic ions such as sodium and magnesium, among others. Sodium, the largest inorganic constituent of the sludge samples, may originate from the transesterification catalysts $(\mathrm{NaOH}){ }^{28}$ Along with other previous identified biodiesel elements, the residues containing sodium may decant in the bottom of the plant storage tanks after the biodiesel production if the cleaning process is insufficient. The engines damage caused by corrosion and the deterioration of biofuel itself can be induced by the presence of $\mathrm{Na}, \mathrm{K}, \mathrm{Ca}$, and $\mathrm{Mg}$. In addition, the presence of $\mathrm{Ca}$ and $\mathrm{Mg}$ increases the formation of sediments and soaps in the combustion chamber, leading to damages in some engine parts. Neutralization and water wash reactions are effective actions recommended for the removal of these damaging compounds. ${ }^{29}$

With the intention of identifying the presence of microorganisms with potential deteriogenic in the sediment of the storage tanks, twelve fungi and bacteria were isolated, identified and characterized. The literature has already acknowledged most of the genera as being of microorganisms with degrading potential. The genus
Micrococcus is described in the literature as a genus of fueldeteriogenic microorganisms. ${ }^{30}$ The genera Curtobacterium, Bacillus, and Microbacterium have also been related to the degradation of hydrocarbons, and the genus Cellulomonas have been related to cellulose degradation. ${ }^{31-35}$ The genus Penicillium is found in the most diverse environments and is widely discussed in the literature as a deteriogenic of diesel and biodiesel. ${ }^{36}$

Of twelve isolated microorganisms, nine presented enzymatic activity in the evaluated culture media. These media are widely used for the prospection of microorganisms with lipase production capacity, which have a well-established industrial importance. ${ }^{16}$ Lipases belong to the hydrolases group, which together with the esterases, are involved in the hydrolysis of esters, glycerines, and long-chain fatty acids..$^{37}$ The mechanisms involved in the biodegradation process of biodiesel remain unclear. A probable route for the biodegradation of fatty acids ester would involve the participation of enzymes such as esterases (carboxylic-ester hydrolases; Enzyme Commission (EC) 3.1.1.1) and lipases (triacylglycerol acyl hydrolases; EC 3.1.1.3). ${ }^{38}$ Initially, a hydrolysis of a methyl or ethyl ester by an esterase (or lipase) would produce a fatty acid and an alcohol. ${ }^{39,40}$ In the second step, the fatty acids would be oxidized via $\beta$-oxidation, incorporating their final products into the Krebs cycle. These final products could be used in the metabolism for the cellular biomass synthesis, for example. ${ }^{39-41}$ The microorganisms found in the sludge of the storage tanks bottom were able to produce enzymes related to the degradation of biodiesel. This finding, along with the data reported in the literature, suggests that the sediment may have a deteriogenic capacity not yet investigated.

\section{Deteriogenic capacity of sludge native microorganisms}

The sludge formation from biotic and abiotic degradation processes has been investigated during the storage of diesel and its blends with biodiesel. Since the beginning of biodiesel use, the user community has noticed a higher tendency to sludge formation during the storage. ${ }^{42,43}$ The sediment in B100 storage tanks from biodiesel plants is not evident because it can be reused during the process of biodiesel formation. The chemical nature of this residue has already been well explored in the literature. ${ }^{20-22}$ The sludge is in constant contact with the biodiesel during production and it is only drained a few times a year. However, no effort has been made to verify whether this sludge could be a source of contamination by deteriogenic biodiesel microorganisms, which in favorable conditions could grow and degrade the stored fuel. Our experiments 
demonstrated that the native microbial community from the sludge was not capable to grow under the conditions established, moreover, the lack of biomass detected in this treatment may indicate that the microbial population was low in density. These results indicated that the biodiesel that went through the entire distribution chain and was assigned to the experiment (CR treatment) had a microbial community suitable to grow and form biomass using biodiesel as substrate.

The microbial growth in fuels produces several metabolites such as carboxylic acids, alcohols, and ketones. ${ }^{44,45}$ However, the buffering of the culture media used as the aqueous phase of the experiments can mask the detection of these metabolites. ${ }^{46}$ Bento et al. ${ }^{44}$ observed a decrease in the $\mathrm{pH}$ (from 7.0 to 4.8 ) of the $\mathrm{BH}$ medium during the growth of the filamentous fungus Aspergillus fumigatus in diesel oil as carbon source. The aqueous phase was evaluated by solid phase microextraction (SPME) and several compounds were identified as alcohols, aldehydes, ketones and carboxylic acids, such as propionic acid. In the first degradation stage, saturated and unsaturated esters are transformed by microorganisms through $\beta$-oxidation, producing organic acids. ${ }^{45}$ Oxidation products, metabolites produced during the hydrocarbon degradation can decrease the $\mathrm{pH}$ of the aqueous phase during the storage and accelerate the corrosion processes of storage tanks. ${ }^{42}$ Liang et al. ${ }^{47}$ characterized the microbial community of oily wastewater and its role in the degradation of marine diesel (F76 and FT-F76) and in the corrosion of carbon steel under anaerobic conditions. The presence of compounds, such as branched alkanes (C13-C19), was identified in the oily waste water. In addition, a number of linear alkanes (C10-C14) and potential acid metabolites associated with the biodegradation of hydrocarbons (benzoic acid, hexanoic acid, hexadecanoic acid, and octadecanoic acid) were detected. The results obtained in the chemical characterization of the sludge indicate that the $\mathrm{pH}$ decrease in the aqueous phase of the BI treatment is probably related to the oxidation products (free fatty acids, alcohols, aldehydes and ketones) produced by the presence of the sampled sediment used as inoculum.

Monitoring of the aqueous phase by GC-FID confirmed the presence of non-microorganism compounds, which could alter the $\mathrm{pH}$ of the mineral minimal medium. Esters from the oil phase migrated to the aqueous phase and could have been consumed by the microorganisms from the contaminated treatments, however, this was not observed. These results suggest that the native microbiota from biodiesel as received were not able to degrade the monitored esters from the aqueous phase. Other authors have used a similar methodology to detect esters from the oil phase of aqueous phases. ${ }^{48,49}$ These authors observed the anaerobic biodegradation of soybean biodiesel and diesel mixtures under methanogenic and sulfate reduction conditions. They concluded that with the increase of the biodiesel fraction added to the diesel, the biodegradation rate of the oil phase was correlated with the concentration of FAMEs soluble in water.

The statistical reduction in the esters observed in BI treatment could indicate a consumption by the microorganisms, but this treatment did not have biomass produced by the microbial growth, suggesting an abiotic degradation of the monitored esters. This reduction may also be associated with the natural degradation processes (oxidation and hydrolysis) intensified by the presence of sludge collected from storage tanks. The excess of metal ions can catalyze oxidation reactions and polymerization of hydrocarbons ${ }^{29}{ }^{2}$ The ions detected in the sludge sample by FAAS analysis may have been also responsible for the reduction of the esters in the aqueous phase of the BI treatment. In some samples (CR t2 and BI t60), C22:1 and/or C20:3 esters appeared at day 60 of incubation and were not detected in the aqueous phase at the initial time. These results suggest that the esters that migrated in the early times were rapidly transformed and/or consumed by the microbiota. Another possibility is that long-chain esters, which have a higher hydrophobic capacity, took longer to migrate than the other components.

Although these elements present in the aqueous phase, as evidenced by the results, were not used as a carbon source for contaminated treatments, the microbial population may have obtained its nutrients for growth directly from the oil phase. The set of spectra generated from the oil phase of all treatments by the infrared technique suggests that after 60 days of simulated storage, the structure of carbonic chains in the biodiesel was modified probably due to abiotic degradation in all samples, including the control. Based on the PCA results, we can assume that the CR treatment showed a tendency to biodegradation, since autochthonous microorganisms from the transportation system and fuel storage were detected in these samples. However, according to the spectra generated by the infrared technique (Figure 4), the degradation was not significant. The graphs of PC2 weights showed that the control samples and those of the BI treatment preserved their structures in a similar way. Therefore, the observed difference between these samples and the B100 t0 samples may suggest that the sludge may have interfered in the composition of the experimental biodiesel. This interference may have occurred when the sludge was added and diluted in the biodiesel samples from the BI treatment. Previous studies detected low ester degradation by microorganisms under 
similar growth conditions. ${ }^{42,50}$ Other compounds such as glycerol, mono-, di-, and non-esterified triglycerides, and glycoside sterols may be used as a carbon source for the microbial growth. Other authors used the infrared spectroscopy technique to detect the biodegradation of diesel and biodiesel fuels (B5 and B10), but we could not correlate the differences found for the biodegradation process. ${ }^{51}$

\section{Conclusions}

The chemical evaluation of the sediment indicated the presence of fatty acid esters and metallic ions; glucosides steroids were not detected. Seven bacteria and five filamentous fungi were isolated, evidencing a cultured microbial community associated to the sediment. However, the microbial population from the collected sludge was not able to produce significant biomass during the 60-day experiment in the presence of biodiesel as a carbon source and minimal mineral medium as a source of nutrients. Probably due to the low initial microbial density, the low degradation values suggest that the evaluated sludge was not a potential deteriogenic source during the storage of biodiesel in up to 60 days of incubation.

\section{Acknowledgments}

The authors would like to thank LAB-BIO/UFRGS, the Institute of Chemistry/UFRGS, Instituto Nacional de Tecnologia (INT), CNPq and CAPES for the grants awarded, and the Biodiesel Plant 3 Tentos for the samples and technical support.

\section{References}

1. Agência Nacional do Petróleo, Gás Natural e Biocombustíveis (ANP); Lei No. 11.097, de 13 de janeiro de 2005, Dispõe sobre a Introdução do Biodiesel na Matriz Energética Brasileira; Altera as Leis Nos. 9.478, de 6 de Agosto de 1997, 9.847, de 26 de Outubro de 1999 e 10.636, de 30 de Dezembro de 2002; e dá Outras Providências, DOU, Brasília, 2005. Available at http:// www2.camara.leg.br/legin/fed/lei/2005/lei-11097-13-janeiro2005-535383-normaatualizada-pl.pdf, accessed in April 2018.

2. Knothe, G.; Razon, L. F.; Prog. Energy Combust. Sci. 2017, 58, 36.

3. Agência Nacional de Petróleo, Gás Natural e Biocombustíveis (ANP); Resolução ANP No. 45, de 25/08/2014. Available at http:// nxt.anp.gov.br/NXT/gateway.dll?f=templates $\& \mathrm{fn}=$ default. htm\&vid=anp:10.1048/enu, accessed in April 2018.

4. Bento, F. M.; Peralba, M. C. R.; Ferrão, M. F.; Zimmer, A. R.; Azambuja, A. O.; Barbosa, C. S.; Bücker, F.; Cazarolli,
J. C.; Quadros, P. D.; Beker, S. A. In Armazenagem e Uso de Biodiesel: Problemas Associados e Formas de Controle, vol. 1, $1^{\text {a }}$ ed.; Suarez, P.; Pinho, D., eds.; CDT: Brasília, UNB, 2016, ch. 5 .

5. Bezerra, K. D. S.; Antoniosi Filho, N. R.; Quim. Nova 2015, $38,498$.

6. Bondioli, P.; Cortesi, N.; Mariani, C.; Eur. J. Lipid Sci. Technol. 2008, 110, 120.

7. Pinho, D. M. M.; Suarez, P. A. Z.; Meneghetti, S. M. P.; Rangel, E. T. In Armazenagem e Uso de Biodiesel: Problemas Associados e Formas de Controle, vol. 1, 1 ${ }^{\mathrm{a}}$ ed.; Suarez, P.; Pinho, D., eds.; CDT: Brasília, UNB, 2016, ch. 1.

8. Meneghetti, S. P.; Meneghetti, M. R.; Brito, Y. C.; Rev. Virtual Quim. 2013, 5, 63.

9. Zimmer, A. R.; Oliboni, A.; Viscardi, S. L.; Teixeira, R. M.; Ferrão, M. F.; Bento, F. M.; Biofuel Res. J. 2017, 4, 627.

10. http://www.abntcatalogo.com.br/norma.aspx ?ID=322742, accessed on April 8, 2017.

11. Beker, S. A.; Machado, M. E.; Maciel, G. P. S.; Silva, R.; Cataluña, R.; Caramão, E. B.; Bento, F. M.; J. Braz. Chem. Soc. 2016, 27, 91.

12. https://www.astm.org/Standards/E1212.htm, accessed on May 8, 2017.

13. Bushnell, L. D.; Haas, H. F.; J. Bacteriol. 1941, 41, 653.

14. Ferreira, M. E.; Grattapaglia, D.; Introdução ao Uso de Marcadores Moleculares em Análise Genética; EMBRAPACENARGEN: Brasília, 1996.

15. https://blast.ncbi.nlm.nih.gov/Blast.cgi, accessed in April 2018.

16. Hasan, F.; Shah, A. A.; Hameed, A.; Biotechnol. Adv. 2009, 27 , 782.

17. XLSTAT-Pro, Data Analysis and Statistical Solution for Microsoft Excel; Addinsoft: Paris, France, 2011.

18. Helfer, G. A.; Bock, F.; Marder, L.; Furtado, J. C.; da Costa, A. B.; Ferrão, M. F.; Quim. Nova 2015, 38, 575.

19. Deshpande, M. S.; Rale, V. B.; Lynch, J. M.; Enzyme Microb. Technol. 1992, 14, 514.

20. Plata, V.; Gauthier-Maradei, P.; Romero-Bohórquez, A. R.; Kafarov, V.; Castillo, E.; Biomass Bioenergy 2015, 74, 6.

21. Bondioli, P.; Eur. J. Lipid Sci. Technol. 2009, 111, 814.

22. Fernandes Jr., V. J.; Araujo, A. S.; Vinhado, F. S.; Pivesso, P. R.; Quim. Nova 2012, 35, 1901.

23. Dunn, R. O.; J. Am. Oil Chem. Soc. 2012, 89, 1509.

24. Mahmudul,H.M.;Hagos,F.Y;;Mamat, R.;Adam,A.A.;Ishak,W.F. W.;Alenezi, R.; Renewable Sustainable Energy Rev. 2017, 72, 497.

25. Pinho, D. M.; Santos, V. O.; dos Santos, V. M.; Oliveira, M. C.; da Silva, M. T.; Piza, P. G.; Pinto, A. C.; Rezende, M. J. C.; Suarez, P. A.; Fuel 2014, 136, 136.

26. Erinç, H.; Tekin, A.; Özcan, M. M.; Grasas Aceites (Sevilla, Spain) 2009, 60, 375.

27. Piironen, V.; Lindsay, D. G.; Miettinen, T. A.; Toivo, J.; Lampi, A. M.; J. Sci. Food Agric. 2000, 80, 939. 
28. Verma, P.; Sharma, M. P.; Renewable Sustainable Energy Rev. 2016, 62, 1063.

29. Banga, S.; Varshney, P. K.; J. Sci. Ind. Res. 2010, 69, 575.

30. Soriano, A. U.; Martins, L. F.; Ventura, E. S. A.; de Landa, F. H. T. G.; Valoni, E. A.; Faria, F. R. D.; Ferreira, R. F.; Faller, M. C. K.; Valério, R. R.; Leite, D. C. A.; Carmo, F. L.; Peixoto, R. S.; Int. Biodeterior. Biodegrad. 2015, 99, 102.

31. Pavić, A.; Stanković, S.; Saljnikov, E.; Krüger, D.; Buscot, F.; Tarkka, M.; Marjanović, Ž.; Fungal Ecol. 2013, 6, 527.

32. Sandhu, S. K.; Mathur, A.; Gupta, R.; Puri, S. K.; Adsul, M. In Waste to Wealth; Singhania, R.; Agarwal, R.; Kumar, R.; Sukumaran, R., eds.; Springer: Singapore, 2018, p. 441.

33. Ferreira, L.; Rosales, E.; Danko, A. S.; Sanromán, M. A.; Pazos, M. M.; Process Saf. Environ. Prot. 2016, 101, 19.

34. Yadav, A. K.; Manna, S.; Pandiyan, K.; Singh, A.; Kumar, M.; Chakdar, H.; Kashyap, P. L.; Srivastava, A. K.; Microbiology 2016, 85, 56.

35. Qin, W.; Zhu, Y.; Fan, F.; Wang, Y.; Liu, X.; Ding, A.; Dou, J.; Biochem. Eng. J. 2017, 121, 131.

36. Allsopp, D.; Seal, K.; Gaylarde, C.; Bento, F. M.; Shirakawa, M.; Saad, D. S.; Introdução à Biodeterioração; UFRGS: Porto Alegre, 2016.

37. Lopes, D. B.; Fraga, L. P.; Fleuri, L. F.; Macedo, G. A.; Food Sci. Technol. (Campinas) 2011, 31, 603.

38. Casas-Godoy, L.; Duquesne, S.; Bordes, F.; Sandoval, G.; Marty, A. In Lipases and Phospholipases SE-1, vol. 861; Sandoval, G., ed.; Humana Press; New York, NY, USA, 2012, p. 3-30.

39. Hausmann, S.; Jaeger, K. E. In Handbook of Hydrocarbon and Lipid Microbiology; Timmis, K., ed.; Springer: Berlin, 2010, p. 1099.
40. Nelson, D. L.; Cox, M. M.; Princípios de Bioquímica de Lehninger; Artmed Editora: Porto Alegre, 2014.

41. Khoury, R. R.; Ebrahimi, D.; Hejazi, L.; Bucknall, M. P.; Pickford, R.; Hibbert, D. B.; Fuel 2011, 90, 2677.

42. Bücker, F.; Santestevan, N. A.; Roesch, L. F.; Jacques, R. J. S.; Peralba, M. C. R.; Camargo, F. A. O.; Bento, F. M.; Int. Biodeterior. Biodegrad. 2011, 65, 172.

43. Yaakob, Z.; Narayanan, B. N.; Padikkaparambil, S.; Renewable Sustainable Energy Rev. 2006, 35, 136.

44. Bento, F. M.; Beech, I. B.; Gaylarde, C. C.; Englert, G. E.; Muller, I. L.; World J. Microbiol. Biotechnol. 2005, 21, 135.

45. Aluyor, E. O.; Obahiagbon, K. O.; Ori-jesu, M.; Sci. Res. Essays 2009, 4, 543.

46. Cazarolli, J. C.; de Quadros, P. D.; Bücker, F.; Santiago, M. R. F.; Piatnicki, C. M. S.; Peralba, M. D. C. R.; Cavalcanti, E. H. S.; Bento, F. M.; Biofuel Res. J. 2016, 3, 514.

47. Liang, R.; Duncan, K. E.; Le Borgne, S.; Davidova, I.; Yakimov, M. M.; Suflita, J. M.; J. Biotechnol. 2017, 256, 68.

48. Wu, S.; Yassine, M. H.; Suidan, M. T.; Venosa, A. D.; Water Res. 2015, 87, 395.

49. Wu, S.; Yassine, M. H.; Suidan, M. T.; Venosa, A. D.; Chemosphere 2016, 161, 382.

50. Cazarolli, J. C.; Guzatto, R.; Samios, D.; Peralba, M. D. C. R.; Cavalcanti, E. H. D. S.; Bento, F. M.; Int. Biodeterior. Biodegrad. 2014, 95, 364.

51. Souza, M. M.; Colla, T. S.; Bücker, F.; Ferrão, M. F.; Huang, C. T.; Andreazza, R.; Camargo, F. A. O.; Bento, F. M.; Int. Biodeterior. Biodegrad. 2016, 110, 141.

Submitted: January 11, 2018 Published online: April 11, 2018 